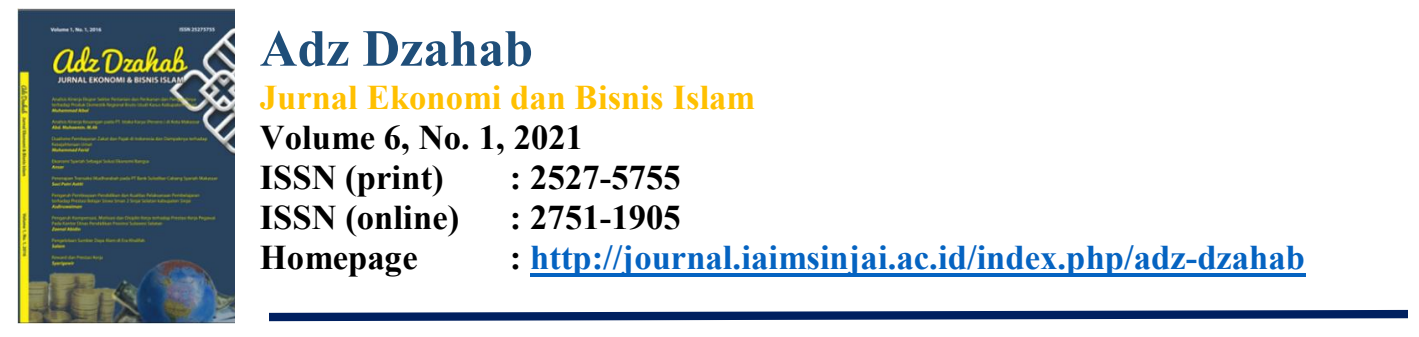

\title{
Kewirausahaan Ditengah Revolusi Industri 4.0 : Teori Dan Konsep Tinjauan Ekonomi Islam
}

\author{
Muhammad Akbar' ${ }^{1}$, Nurhayani' ${ }^{2}$ Damayanti ${ }^{3}$, Rahmatullah $^{4}$ \\ ${ }^{1}$ Universitas Islam Negeri Alauddin Makassar \\ ${ }^{2}$ Institut Agama Islam Muhammadiyah Sinjai \\ ${ }^{3}$ Institut Agama Islam Muhammadiyah Sinjai \\ ${ }^{4}$ Institut Agama Islam Muhammadiyah Sinjai \\ E-mail: bungakbar71@gmail.com Tlp:+6285399139927
}

\begin{abstract}
Abstrak
Di tengah trend perkembangan kewirausahaan yang meningkat di Indonesia, dunia industri tak terkecuali praktek kewirausahaan tengah menghadapi revolusi Industri 4.0. Dimana Revolusi Industri 4.0 adalah gabungan Cyber Phisical System (CPS) dan Internet of Thing and Services (IoT dan Ios) yang memadukan kehidupan nyata dan maya. Pada sektor Kewirausahaan sendiri kehadiran industri 4.0 dapat dimanfaatkan pelaku usaha pemula dalam merintis usaha dengan cepat serta dapat pula menjadi hambatan terhadap pelaku usaha yang kurang cermat dalam melihat peluang. Islam menggambarkan karakter tersendiri seorang wirausaha yang sesuai dalam Al-Quran dan Hadis serta keteladanan Rasulullah diantarana adalah : iman, takwa, moralitas, shiddiq (jujur), amanah (dipercaya), tabligh (memiliki sifat komunikatif), fathanah (memiliki kecerdasan), disiplin, visioner, dan empati atau peduli. Ada dua pendekatan yang dapat dijadiakan sebagai strategi dalam membangun dan menghadapi revolusi industri 4.0, yaitu dengan pendekatan sumber daya dan pendekatan pengetahuan. Pada pendekatan sumberdaya ini, ada empat hal mendasar yang mesti dibangun dalam pribadi wirausaha, yaitu kemampuan menggerakkan, kemampuan mengorganisir, professional dengan menerapkan nilai-nilai islam, teladan dalam bentuk keteladanan dalam pribadi Rasulullah. Selanjutnya pada pendekatan pengetahuan ini, perlunya memahamkan literasi ekonomi dalam nilai-nilai islam yang bersumber pada Al-Quran dan hadis.
\end{abstract}

Kata kunci: Kewirausahaan, Revolusi Industri 4.0, Ekonomi Islam

\section{Pendahuluan}

Kewirausahaan merupakan salah satu solusi yang tepat dalam meningkatkan taraf kesejahteraan serta mengurangi angka pengangguran di negara-negara berkembang seperti Indonesia. Dalam beberapa dekade kebelakang tidak bisa dipungkiri bahwa minat wirausaha di Indonesia sangat rendah sehingga penduduk yang melakukan kewirausahaan terbilang kecil. Menteri Perdagangan Enggartiasto Lukita menyampaikan bahwa pada tahun 2018 hanya 3,1 persen dari total jumlah penduduk Indonesia yang berwirausaha, hal ini berbeda jauh dengan negara-negara maju yang mencapai 14 persen dari jumlah penduduknya (Movanita, 2019). Ada banyak penyebabnya secara psikologis yang terjadi dimasyarakat sehingga timbulnya sikap negatif dalam cara pandang yang berakibat pada kurang berminatnya terhadap profesi wirausaha. Sebagian besar masarakat berpandangan bahwa profesi wirausaha merupakan profesi kurang terhormat dan pekerjaan rendah, serta sumber penghasilan tidak stabil. Seorang wirausaha bersifat agresif, suka bersaing, egois, tidak jujur, kikir, dan sebagainya (Rusdiana, 2018). 


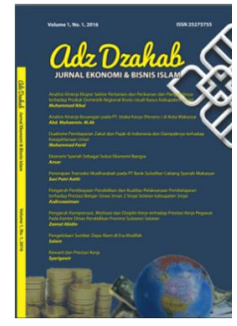

Adz Dzahab

Jurnal Ekonomi dan Bisnis Islam

Volume 6, No. 1, 2021

ISSN (print) : 2527-5755

ISSN (online) : 2751-1905

Homepage : $\quad$ http://journal.iaimsinjai.ac.id/index.php/adz-dzahab

Namun pada beberapa tahun belakangan ini, pertumbuhan kewirausahaan mulai dapat terlihat secara signifikan. Hal ini tentu suatu hal yang positif bagi Indonesia yang menjadi Negara berkembang dengan jumlah penduduk yang cukup besar. Penyerapan tenaga kerja pada sektor wirausaha akan membantu pemerintah dalam penciptaan lapangan kerja baru (Sartono dkk, 2014). Dengan begitu kewirausahaan yang masif dari perkotaan hingga menyentuh ke daerah pelosok akan merangsang pertumbuhan ekonomi kearah yang lebih baik. .

Ditengah trend perkembangan kewirausahaan yang meningkat di Indonesia, dunia industri tak terkecuali praktek kewirausahaan tengah menghadapi revolusi Industri 4.0. Dimana Revolusi Industri 4.0 adalah gabungan Cyber Phisical System (CPS) dan Internet of Thing and Services (IoT dan Ios) yang memadukan kehidupan nyata dan maya (Prasetyo dan Sutopo 2018). Renal Gasali mengatakan dalam menghadapi revolusi industri 4.0, praktek kewirausahaan dipaksakan untuk berpacu dengan kecepatan informasi berbasis digital. Pegiat kewirausahaan yang tidak mampu untuk beradaptasi dengan kecepatan informasi dan perubahan-perubahan yang sangat dinamis dan sarat akan persaingan, akan mengalami banyak kesulitan dalam praktek kesehariannya (Baharun dan Niswa 2019).

Globalisasi melahirkan perubahan tatanan sosial yang menyebabkan permasalahan menjadi semakin kompleks. Bak seperti dua sisi koin, globalisasi membawa dampak positif sekaligus dampak negatif bagi manusia. Bangsa yang memiliki karakter tangguh lazimnya tumbuh berkembang dan semakin maju serta sejahtera (Saptono, 2011). Menteri Perdagangan Enggartiasto Lukita menekankan bahwa Revolusi Industri 4.0 merupakan proses kompetisi percepatan dalam menyampaikan ide lalu menjualnya kepada konsumen. Kunci dalam menghadapi kompetisi industri global adalah menciptakan kebutuhan pasar, selalu belajar, dan meningkatkan produktivitas (Movanita, 2019). Menteri Perindustrian Airlangga Hartarto melakukan kunjungan kerja Ceko dan Jerman Pada tanggal 30 April sampai dengan 4 Mei 2018 dalam rangka upaya mendukung langaka-langkah strategis pemeritah Indonesia dalam mengimplementasikan ekonomi berbasis digital berdasarkan roadmap Making Indonesia 4.0 dalam upaya mempercepat visi nasional untuk memanfaatkan peluang di era industri 4.0 .

Pada sektor Kewirausahaan sendiri kehadiran industri 4.0 dapat dimanfaatkan pelaku usaha pemula dalam merintis usaha dengan cepat serta dapat pula menjadi hambatan terhadap pelaku usaha yang kurang cermat dalam melihat peluang. Industri 4.0 mempengaruhi perubahan perilaku manusia yang signifikan. Penggunaan teknologi internet yang berbasis aplikasi dan jaringan berkembang dengan cepat. Praktek kewirausahaan dengan pengaplikasian ilmu kewirausahaan secara konveksional tidak cukup kuat di tengah kondisi perkembangan industri 4.0. Kewirausahaan baik dari segi teori dan praktek harus berevolusi menuju era digitalisasi.Kewirausahaan dalam bayangan industri 4.0 pada abad ini bukan lagi berbicara persoalan ide dan produk saja, melainkan data dan pengelolaan data serta transaksi yang dihasilkan dari data-data yang terkelolah dengan baik. Kewirausaan harus memfokuskan bisnis model berbasis digital sehingga terhubung dengan kemajuan zaman, dimana semua usaha serba digital dan pembeli melakukan transaksi secara digital pula. Industri 4.0 merupakan praktek baru dalam menghubungkan antara data, orang, layanan, proses, dan sistem berbasis digital untuk mencapai suatu keberhasilan dalam berbisnis (Diandra 2019). Perubahan menuju arah digitalisasi dipandang perlu dalam kemajuan perekonomian di Indonesia. Percepatan informasi dapar mempermudah konsumen dalam menemukan produk atau jasa yang diminatinya, dan digital mempermudah pelaku usaha dalam pemasaran produk atau jasa 


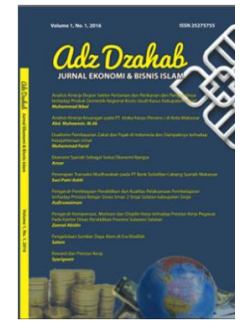

Adz Dzahab

Jurnal Ekonomi dan Bisnis Islam

Volume 6, No. 1, 2021

ISSN (print) : 2527-5755

ISSN (online) : 2751-1905

Homepage : $\quad$ http://journal.iaimsinjai.ac.id/index.php/adz-dzahab

yang diproduksinya sehingga dengan cepat memperoleh keuntungan sebagai nilai tambah yang dapat dimanfaatkan untuk kepentingan perkembangan usaha atau gaya hidupnya.

Kehadiran digitalisasi di Indonesia tepat ditengah semaraknya sistem ekonomi islam hadir sebagai solusi dari sistem kapitalis dan sosialis yang dipandang mengalami penurunan. Muhammad Abdul Mannan mengatakan ekonomi islam merupakan ilmu pengetahuan sosial yang mempelajari masalah-masalah ekonomi masyarakat yang diilhami oleh nilai-nilai islam (Fauziah, 2014). Kewirausahaan secara sederhana menurut pandangan Islam erat kaitannya dengan mencari rezki untuk kelangsungan hidup. Dalam pandangan islam, umat yang berwirausaha akan dicintai Allah. Sebagaimana hadis Rasulullah dari Ibnu Umar, Rasulullah SAW bersabda yang berbunyti :

"Sesungguhnya Allah SWT mencintai seorang mu'min yang bekerja denga giat."

(HR. Imam Tabrani, dalam Al-Mu'jam Al-Aushth VII/380).

Sebagai wirausahawan dituntut untuk memiliki sikap yang inovatif, kreatif, rajin dan tekun. Dalam nilai dan prinsip syariah islam, hal demikian bukan berarti bahwa dalam mencari rezeki demi memenuhi kebutuhan hidup lantas melegalkan segala cara, melainkan selalu berlandaskan kepada prinsip-prinsip syariah yang mengutamakan kehalalan dan nilai kebaikan. Umat Islam diperintahkan untuk mendapatkan pekerjaan yang baik serta berdampak positif untuk dirinya sendiri yang mana akan diapresiasikan dalam bentuk penghargaan, dan jika terjadi sebaliknya atau berbeda akan mendapatkan ganjaran. Allah mengetahui bagaimana seseorang berkerja dengan jujur atau tidak dalam pekerjaanya itu. Sebagaimana Allah SWA berfirman:

"Dan katakanlah: Berkerjanlah kamu, Maka Allah dan RasulNya serta orangorang mukmin akan melihat pekerjaanmu itu, dan kamu akan dikembalikan kepada (Allah) yang mengetahui akan yang ghaib dan yang nyata, lalu di beritakan-Nya kepada kamu apa yang telah kamu kerjakan." (Qs. Taubah: 105)

Namun untuk menjalankan sebuah usaha deperlukan sebuah literasi tentang ekonomi islam. Hal ini diperlukan agar dijadikan sebagai sebuah landasan dalam setiap pengambilan-pengambilan keputusan dalamusaha. Keputusan atau praktek yang menyalahi nilai-nilai dan prinsip dasar dalam islam tentunya sangat di larang dalam islam. Dengan bekal literasi ekonomi islam, kemudian secara tidak sadar akan membentuk karakter dan watak seorang wirausaha sebagaimana karakter dalam islam yang tercermin dalam keteladaan Rasulullah yang mana selalu mengupayakan dengan maksimal mungkin urusan dunia, berdagang untuk kemaslahatan dengan senantiasa berprilaku jujur dan tidak mendatangkan keburukan atau kerugian kepada orang lain serta senantiasa menyandarkan diri kepada Allah SWT sebagai dzat yang meciptakan dan maha memiliki segala apa yang ada di alam semesta.

\section{Hasil Penelitian}

\subsection{Konsep dasar Kewirausahaan}

Kewiraushaan adalah padanan kata dari entrepreneurship dalam bahasa inggris, unternehmer dalam bahasa jerman, Ondernemen dalam bahasa Belanda. Sedangkan di Indonesia diberi nama kewirausahaan. Kata entrepreneur berasal dari bahasa Prancis, yaitu entreprende yang berarti petualang, pengambil resiko, kontraktor, pengusaha (orang yang mengusahakan suatu pekerjaan tertentu), dan pencipta yang menjual hasil ciptaannya. Istilah ini diawali oleh Richard Cantillon pada tahun 1755, yaitu entrepreneurial is an inovator and individul developing something unique and new. Istilah ini kemudian dipopulerkan oleh ekonom J. B Say pada tahun 1803 untuk 


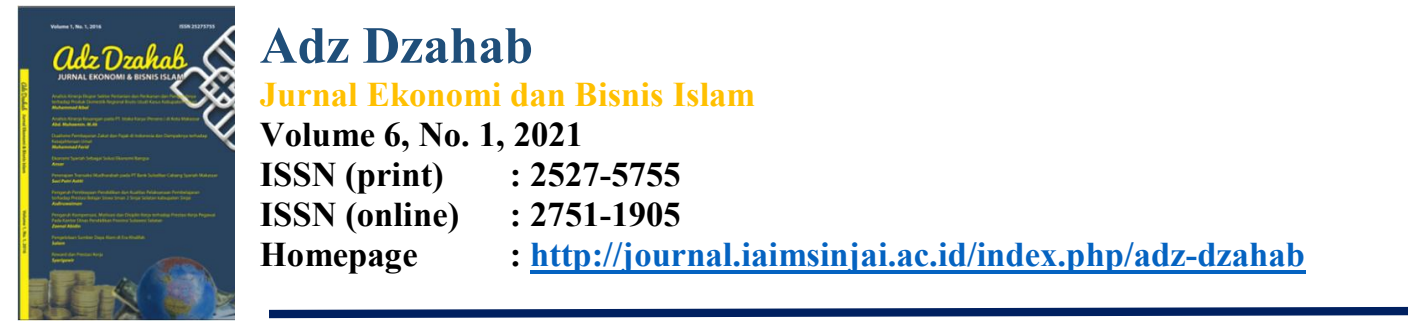

menggambarkan para pengusaha yang mampu mengelola sumber-sumber daya yang dipunyai secara ekonomis (efektif dan efisien) dari tingkat produktivitas yang rendah menjadi lebih tinggi. Selanjutna gagasan ini dibahas secara mendalam oleh Joseph Schumpeter seorang ahli ekonom Jerman pada tahun 1911. Melalui teori pertumbuhan ekonomi, konsep kewirausahaan didudukkan pada posisi yang sangat penting dalam pelaksanaan pembangunan. (Triningtyas 2016).

Konsep kewirausahaan terus berkembang seiring dengan perkembangan pemikiran barat hingga menyebar ke negara-negara lain termasuk Indonesia. Menurut kemendiknas (2010) kewirausahaan adalah suatu sikap, jiwa dan kemampuan untuk menciptakan sesuatu yang baru, yang sangat bernilai dan berguna, baik bagi dirinya sendiri maupun bagi orang lain. Kewirausahaan mendorong minat seseorang untuk mendirikan dan mengelola usaha secara professional. Kewirausahaan juga dapat diartikan sebagai kemampuan kreatif dan inovatif yang dijadikan dasar, kiat, dan sumber daya untuk mencari peluang menuju kesuksesan (Zimmerer, 2002). Pengertian kewirausahaan menurut intruksi presiden RI No.4 tahun 1995; "Kewirausahaan adalah semangat, sikap, prilaku, dan kemampuan seseorang dalam menangani usaha atau kegiatan yang mengarah pada upaya mencari, menciptakan, menerapkan cara kerja, teknologi dan produk baru dengan meningkatkan efisiensi dalam rangka memberikan pelayanan yang lebih baik dan memperoleh keuntungan yang lebih besar.

Dalam berbagai literatur istilah wirausaha sering disamakan dengan istilah wiraswasta, sedangkan dari berbagai pendapat kedua istilah ini sangatlah berbeda. Wiraswasta secara etimologisnya terdiri dari tiga padanan kata yaitu wira, swa dan ta. Wira adalah manusia unggul, teladan, berbudi luhur, berjiwa besar, berani, pahlawan/pendekar kemajuan yang memiliki watak agung. Swa adalah sendiri Ta adalah berdiri ,Jadi Wiraswasta adalah keberanian, keutamaan serta keperkasaan dalam memenuhi kebutuhan serta memecahkan persoalan hidup dengan kekuatan yang ada pada diri sendiri (Sartono dkk, 2014). Sedangkan Wirausaha atau entrepreneur yang berasal dari kata bahasa Perancis entreprendre yang berarti melakukan (to undertake) atau mencoba (trying). Dalam bahasa Indonesia yang sederhana wirausaha dapat dimaknai sebagai sebuah kemampuan (an ability) yang di dalamnya termasuk dalam artian 'usaha' (effort), aktivitas, aksi, tindakan dan lain sebagainya untuk menyelesaikan suatu tugas (task) (Frinces 2010).Wirausaha mengacu pada orang yang melaksanakan proses penciptaan kesejahteraan/kekayaan dan nilai tambah melalui tindakan dari pemahaman dan gagasan yang dimiliki hingga menjadi kenyataan. Dengan kata lain seorang wirausaha adalah orang yang mampu mengubah gagasan menjadi realitas (Al Idrus 2017).

Wirausaha adalah orang yang dipenuhi dengan kreatifitas, dinamis dan inovatif, dan berani mengambil risiko serta siap menghadapi berbagai tantangan yang tidak terprediksi sebelumnya demi mencapai kesuksesan. Dari keberanian yang dimiliki, seorang wirausaha terus mengembangkan berbagai bisnis-bisnis baru hingga kompetitif dan dapat menawarkan berbagai macam pilihan (Frinces 2010). Dengan demikian sangat jelas perbedaan antara wirausaha dan wiraswasta dimana secara sederhana wirausaha dipenuhi dengan kreatifitas dan inovasi sedangkan sebaliknya wiraswasta tidak memiliki pengembangan kreatifitas dan inovasi, bekerja untuk kebutuhan semata dimana cenderung monoton terhadap usaha yang di gelutinya tanpa melakukan pengembangan usaha-usaha baru.

\subsection{Kewirausahaan dalam era Industri 4.0}

Secara fundamental akan terjadi perubahan terhadap segala tatanan kehidupan manusia, perubahan ekonomi dunia, komunitas atau kelompok, dan merubah identitas 


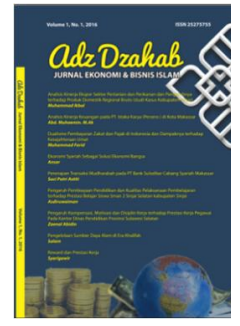

Adz Dzahab

Jurnal Ekonomi dan Bisnis Islam

Volume 6, No. 1, 2021

ISSN (print) : 2527-5755

ISSN (online) : 2751-1905

Homepage : $\quad$ http://journal.iaimsinjai.ac.id/index.php/adz-dzahab

manusia itu sendiri sebagai akibat dari adanya revolisi industri 4.0 (Schwab 2017). Artinya bahwa perlunya suatu sikap kehati-hatian dalam menghadapi perkembangan dan perubahan zaman tak terkecuali dunia kewirausahaan. Kewirausahaan dalam revolusi industri 4.0 mengalami dampak yang sangat signifikan, mulai dari perubahan perilaku pasar hingga pada pola dalam berbisnis. Hal ini disebabkan karena perubahan dan kecepatan informasi yang tidak dapat dibendung oleh wirausaha.

Pertemuan forum ekonomi dunia (WEF ASEAN) tahun 2018 menyepakati untuk fokus pada pembangunan kepercaaan diri, berinovasi serta siap melayani segala kepentingan jangka panjang pemerintah, masarakat dan bisnis setiap negara dalam menghadapi kemajuan teknologi di era revolusi industri (berita Nhan Dan online, 2018). Hal ini menandakan bahwa integrasi dan konektifitas antara perusahaanperusahaan di Asia Tenggara tidak bisa dipungkiri adanya, dengan begitu akan membuka peluang-peluang bisnis baru disektor ASEAN. Kewirausahaan saat ini bukan lagi berbicara soal individual melainkan adalah kolaborasi, sinergitas dan saling melengkapi satu dengan yang lainnya. Kewirausahaan bukan lagi milik korporasi melainkan bisa dimiliki oleh semua orang tanpa adanya batas usia, waktu, dan jarak yang mana hal ini dapat berubah bahkan dalam hitungan detik (Diandra 2019).

Perkembangan teknologi berbasis jaringan internet dapat memberikan nilai tambah, hal ini dapat dilihat dari pertukaran informasi dan komunikasi tidak hanya terjadi antar manusia dan mesin saja, namun antar mesin itu sendiri (Roblek 2016). Kewirausahaan di zaman serba digitalisasi memiliki tantangan tersendiri, dimana interaksi pelaku usaha tidak hanya sesama manusia saja semata melainkan juga dengan mesin yang terkoneksi dengan jaringan. Era industri ini berkembang melalui konektivitas dan digitalisasinya serta mampu menaikkan efsiensi manufaktur dan kualitas produk. Dibandingkan sistem tradisional yang masih mengandalkan kemampuan manusia dalam pengerjaannya, kecepatan dan efisiensi kinerja akan tercipta di dalam proses produksi ketika manusia dan mesin sudah terintegrasi melalui mesin itu sendiri, dan ini akan memeberikan nilai tambah (Vaidya 2018)

Industri 4.0 yang terkoneksi secara global melalui internet banyak melahirkan aplikasi berbasis jaringan yang dapat memotong gerak, langkah, dan bahkan sistem. Baik sistem produksi, sistem komunikasi, dan sistem transaksi dalam tatanan kehidupan zaman ini (Diandra 2019). Dalam dunia kewirausahaan sendiri berbagai macam aplikasi online shop seperti (Toko Pedia, Lazada, Shopee dan lain-lain) merupakan bentuk pemotongan sistem pemasaran yang merupakan sebuah akibat dari digitalisasi. Hal ini tentunya memberikan kemudahan terhadap seorang wirausaha, karena dengan adanya aplikasi yang berbasis jaringan akan memudahkan seorang pengusaha untuk memasarkan hasil produksi (barang atau jasa) kepada masarakat luas tanpa dibatasi jarak. Dalam sistem transaksi kemudian juga ikut mengalami perubahan, dimana transaksi pembayaran tidak lagi dilakukan secara offline atau bertemu langsung melainkan dengan berbagai platform pembayaran (OVO, GOPAY, DANA) yang berkembang melalui sistem jaringan dan terkoneksi dengan sistem perbankkan.

Implikasi dari adanya revolusi industry 4.0 pada sektor ekonomi yaitu adanya peningkatan kewirausahaan yang sangat pesat (Hamdam 2018). Bisnis e-commerce misalnya, cukup memberikan dampak positif dalam perkembangan dunia bisnis. Dengan adanya bisnis ini memberikan peluang bagi para pengusaha baik pemula maupun yang sudah eksisi. Namun bisnis ini juga memiliki sisi negatif jika dilihat dari beberapa permasalahan yang sering terjadi, misalnya maraknya penipuan yang sering dilakukan baik dari pihak pelaku bisnis maupun konsumen, kompetitor, penipu dan hacker (Sundari 2019). Dalam revolusi Industri 4.0 hal ini tidak dapat dielakkan, sudah terlalu banyak 


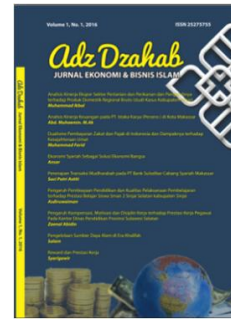

Adz Dzahab

Jurnal Ekonomi dan Bisnis Islam

Volume 6, No. 1, 2021

ISSN (print) : 2527-5755

ISSN (online) : 2751-1905

Homepage : $\quad$ http://journal.iaimsinjai.ac.id/index.php/adz-dzahab

penipuan terjadi dimasyarakat mulai dari yang terkecil persoalan pembelanjaan yang tidak sesuai dengan bahan (bukan original) atau warna yang dipesan, sampai pada yang terbesar tentang penipuan yang mengatasnamakan perusahaan tertentu untuk mengambil uang seseorang.

\subsection{Kewirausahaan dalam Presfektif Islam}

Dalam ajaran agama Islam menuntut kesempurnaan dalam berbagai hal dengan dasar bahwa agama Islam adalah agama yang paling sempurna. Bentuk kesempurnaan dalam kehidupan misalnya, Islam menganjurkan ummatnya untuk mandiri dalam hidup dengan cara bekerja atau berwirausaha dengan jalan yang benar. Kewirausahaan dalam islam digolongkan kedalam kegiatan mua'malah. Sesungguhnya mua'malah adalah bagian utuh yang sempurna dari sistem Islam. Samir Abdul Hamid Ridwan (1996) mengatakan bahwa ibadah dan muamalat merupakan dua sisi syariah Islam. Laksana satu tubuh ang saling berkaitan dan keduanya satu tujuan yaitu dalam rangka ibadah dan ketaatan kepada Allah Swt). Dalam pengertian umum Mua'malah adalah hubungan antara sesama manusia, dalam hal terminologi al fiqh al Islami adalah Kumpulan hukum-hukum syariah yang berkaitan dengan interaksi duniawi seperti jual-beli, utang-piutang, sewamenyewa dan lainnya (Habibullah 2018).

Dalam Islam terdapat tiga pilar yang mendukung kewirausahaan (Gumusay 2015). Pilar pertama yaitu aspek spiritual agama dan hubungan manusia dengan Allah, hal ini mengacu pada tujuan penciptaan manusia sebagai hambah yang menghambakan diri untuk memperoleh rida Allah semata. Pilar kedua yaitu mengejar terbukanya peluang yang luas, hal ini mengacu pada konsep kewirausahaan bahwa pelaku usaha adalah seseorang yang mempunai pola pikir kreatif dan inovatif. Pilar ketiga adalah sosial ekonomi atau nilai etika, hal ini mengacu pada sekumpumpulan norma nilai dan perilaku terpuji dalam islam pada setiap kegiatan seorang wirausaha.

Pada dasarnya berwirausaha harus mampu untuk berfikir kreatif dan berinovasi dalam menciptakan suatu hal yang baru serta berbeda dari yang sudah ada sebelumnya (create newand different) sehingga bisa tercipta peluang usaha. Jauh sebelum munculnya kewirausahaan sebagai pengaplikasian dari ide-ide kreatif dan inofatif untuk memperoleh keberhasilan, konsep ini dalam dunia Islam sudah ditekankan kepada pemeluknya agar supaya dalam urusan duniawi hendaklah untuk kreatif dan inovatif sebagaimana dalam sabda Rasululah SAW tentang anjuran untuk kreatif yang berbunyi :

"Barang siapa melakukan hal baru yang baik maka ia mendapat pahalanya dan mendapat pula pahala orang lain yang mengerjakan hal baru yang baik itu.” (HR. Muslim)

Kewirausahaan sebagai bagian dari mua'malah, islam sangat tegas dalam memberikan batasan-batasan melalui fiqh mua'malah atau hukum, norma dan nilai yang berkaitan dengan tindakan manusia dalam hal persoalan dunia, seperti kewirausahaan yang berkaitan dengan jual-beli, utang piutang, bisnis dan lain-lain (haroen 2007). Maksudna ialah mua'malah ini diatur sebaik mungkin agar manusia dapat memenuhi kebutuhan hidup tanpa memberikan kerugian kepada orang lain (habibullah 2018). Norma, aturan serta nilai-nilai dalam berkewirausahaan ini diserap dari podoman Islam yaitu Al-qur'an dan hadis serta ketauladanan Rasulullah dalam berdagang.

Bentuk implementasi dari unsur-unsur yang diserap dalam pedoman Islam sebagai karakter seorang wirausha dalam perspektif Islam (Hijriah 2016), adalah sebagai berikut:

1. Iman

Keimana seorang wirausaha dalam pandangan islam dapat dilihat dari keyakinan seseorang, bahwa segala rezki yang diperolehnya dari usahanya semata-mata bersumber dari Allah dan meyakini bahwa segala sesuatu yang diusahakannya adalah merupakan 


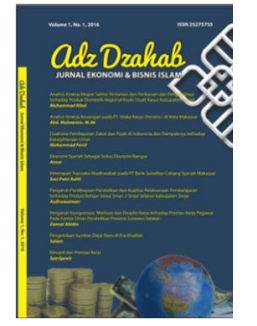

Adz Dzahab

Jurnal Ekonomi dan Bisnis Islam

Volume 6, No. 1, 2021

ISSN (print) : 2527-5755

ISSN (online) : 2751-1905

Homepage : $\quad$ http://journal.iaimsinjai.ac.id/index.php/adz-dzahab

ibadah. Aspek turunan dari unsur iman yang berpotensi bagi kewirausahaan dalam perspektif Islam yaitu mengimani Allah dan rukun iman dalam islam, berusaha dan bertawakkal serta bersukur atas segala yang diperoleh baik lebih maupun kurang.

2. Takwa

Ketakwaan seorang wirausaha dalam pandangan islam dapat dilihat dari prakteknya untuk mengerjakan segala perintah-Nya dan menjauhi segala larangan-nya seperti senantiasa dalam mendirikan sholat wajib dan sunnah, tidak menjual barangbarang haram, senantiasa menghindari riba dan tidak menzalimi orang lain.

3. Moralitas

Moralitas seorang wirausaha dapat dilihat dari kebiasaan membuat kemudahan dan kebaikan seperti tidak berbuat kerusakan dalam transaksi bisnis, memenuhi hak dari orang lain termasuk membayarkan upah tepat waktu, dan selalu mengutamakan kesopanan dalam berucap ataupun berprilaku krpada sesama manusia sebagai ciptaan Allah.

4. Shiddiq (jujur)

Seorang wirausaha sangat dianjurkan untuk bersifat jujur. Dalam islam sangat melarang untuk bersifat bohong /munafik atau melakukan praktek penipuan (Kamaluddin 2019) sebagaimana Allah SWT berfitman dalam surah Al-Muthaffifin ayat 1-3 yang artinya : "Kecelakaan besarlah bagi orang-orang yang curang (yaitu) orang-orang yang apabila menerima takaran dari orang lain mereka minta dipenuhi, dan apabila mereka menakar atau menimbang untuk orang mereka mengurangi”. Dalam hadis, Rasulullah SAW. bersabda, "Pedagang yang jujur dan tepercaya bersama-sama para Nabi, orang shadiqin, dan para syuhada" (H.R. Tirmidzi dan Hakim). Berwirausaha hendaknya senantiasa dilandasi oleh kejujuran. Berwirausaha dengan jujur akan memperoleh kebaikan dan sebaliknya akan memperoleh kehancuran. Kejujuran seorang wirausaha digambarkan dalam keterbukaannya terhadap kekurangan dari produk usahanya, memproduksi produk dengan bahan baku pilihan dan halal.

5. Amanah (dipercaya)

Sifat amanah adalah sifat yang sangat dibutuhkan dalam berbagai aspek kehidupan tak terkecuali dalam berwirausaha. Dalam menjalankan usaha tentu seseorang akan banyak melakukan transaksi, apabila seseorang tersebut tidak amanah maka hal ini akan berdampak besar usahanya (Kamaluddin 2019). Dalam islam hal ini dijelaskan Allah dalam surah An-Anfal yang artinya : "Hai orang-orang yang beriman, janganlah kamu mengkhianati Allah dan Rasul (Muhammad) dan (juga) janganlah kamu mengkhianati amanat-amanat yang dipercayakan kepadamu sedang kamu mengetahui". Amanahnya seseorang wirausaha tercermin dari pelayanan terbaik yang diberikan kepada konsumennya, senantiasa menciptakan produk yang berkualitas dan tidak korup dalam mengelolah modal.

6. Tabligh (memiliki sifat komunikatif)

Komunikasi adalah salah satu hal yang perlu untuk seorang wirausaha. Seseorang yang tidak memiliki sifat komunikatif tentunya akan kesulitan dalam berwirausaha. Tabligh Seorang wirausaha dapat dilihat dari relasi atau jaringan yang dibangun dapat terjaga dan bertahan lama, komunikatif dan ramah serta sopan santun baik dalam melaani maupun memasarkan prodaknya sehingg konsumen tertarik dan membeli barang ataupun jasa tersebut.

7. Fathanah (memiliki kecerdasan)

Dalam islam menjalankan suatu usaha wirausahawan wajib mempunyai kecerdasan (fathanah), melalui kecerdasan seseorang akan menghasilkan ide yang kreatif dan inovatif, sehingga cepat melihat peluang, sekaligus memberikan solusi terhadap 


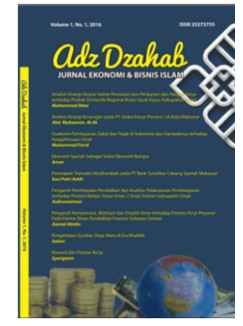

Adz Dzahab

Jurnal Ekonomi dan Bisnis Islam

Volume 6, No. 1, 2021

ISSN (print) : 2527-5755

ISSN (online) : 2751-1905

Homepage : http://journal.iaimsinjai.ac.id/index.php/adz-dzahab

maslah-masalah yang menjadi hambatan. Fatanahnya wirausahawan dapat dilihat dari kepeduliannya terhadap pengetahuan, dengan senantiasa ikut dalam pelatihan-pelatihan atau pembelajaran yang beguna untuk menambah pengetahuan atau skil pada diri dan usahanya sehingga terus berkembang kearah ang lebih baik lagi.

8. Disiplin

Hasil yang baik akan didapatkan apabila seorang wirausaha berprilaku disiplin dalam menjalankan usahanya. Disiplin adalah ketepatan janji terhadap kewajiban baik terhadap waktu, pekerjaan dan sebagainya (Suharyadi dkk 2007). Kedisiplinan seorang wirausaha dapat dilihat dari sikap dan tindakannya dalam memenuhi hak seorang konsumen serta gaji untuk seorang karawan karawannya dibaarkan dengan tepat waktu.

9. Visioner

Seorang wirausaha harus berjiwa visioner dimana memiliki visi yang kuat karena penting terhadap usaha untuk dibawa maju dan berkembang serta keberlangsungan usaha jangka panjang. Sifat ini dapat dilihat dari cara berfikir seorang wirausaha yang selalu berfikir jauh kemasa depan untuk mengembangkan usahanya menjadi terdepan dan terbaik di bidangnya, senantiasa mengembangkan kemampuan dan keterampilan agar mencapai target yang maksimal.

10. Empati atau Peduli

Wujud dari rasa empati dalam pandangan Islam digambarkan sebagai kepedulian terhadap orang lain dengan tindakan menyisihkan sebagian hasil usahanya untuk diberikan dalam bentuk zakat, infak dan wakaf.

Menghadapi zaman yang serba cepat dan tidak terkendali dalam era digitalisasi ini mesti memiliki suatu pondasi yang kuat agar tidak tertinggal dan juga tidak tersesat kepada jalan yang merugi. Ada dua pendekatan yang dapat dijadiakan sebagai strategi dalam menghadapi revolusi industri 4.0, yaitu dengan pendekatan sumber daya dan pendekatan pengetahuan (Wahl 2015). Sumber daya manusia dalam islam dikenal dengan istilah SDI atau sumber daya Insani. Strategi melalui pendekatan sumber daya insani dipandang perlu sebab dengan sumber daya insani yang kompetetif akan mampu bertahan. Sumber daya insani dalam islam berbeda dengan sumber daya manusia dalam ekonomi konvensional. Ada empat hal mendasar yang mesti dimiliki seorang wirausaha dalam islam, yaitu kemampuan menggerakkan, kemampuan mengorganisir, profesional, teladan dalam bentuk keteladanan dalam nilai-nilai islam (Hijriah, 2016). Pembangunan sumberdaya seorang wirausaha harus sejalan dengan pembangunan pengetahuan. Dalam hal ini pengetahuan literasi ekonomi dalam nilai-nilai islam yang bersumber pada AlQuran dan hadis. Wirausaha yang berbekal pada ilmu pengetahuan ekonomi dan kewirausahaan islam akan mampu dalam menghadapi kesulitan dengan terus berpegang teguh pada prinsip dan nilai dasar islam.

\subsection{Literasi Ekonomi Islam}

Literasi dalam pengertian sederhananya merupakan suatu keahlian membaca, menulis dan menghitung yang popular dalam singkatanya adalah CALISTUNG (baca, Tulis dan Hitung) atau melek aksara. Literasi dapat dipahami sebagai kemampuan dalam mengolah informasi, jauh di atas kemampuan, mengurai dan memahami bahan bacaan sekolah. (Pakistianingsih, 2014). Seiring perkembangan zaman literasi tidak lagi berbicara soal baca, tulis dan hitung melainkan jauh lebih luas literasi juga menangkut proses pembelajaran dan keahlian (Manisi, 2013). Kehadiran dan meluasnya pengertianliterasi baru yang telah menyentuh pada ranah proses transformasi ilmu pengetahuan dan keahlian ini kemudian mengakibatkan munculnya berbagai macam literasi pada bidang-bidang yang lain seperti literasi ekonomi islam, literasi kewirausahaan dan sebagainya. 


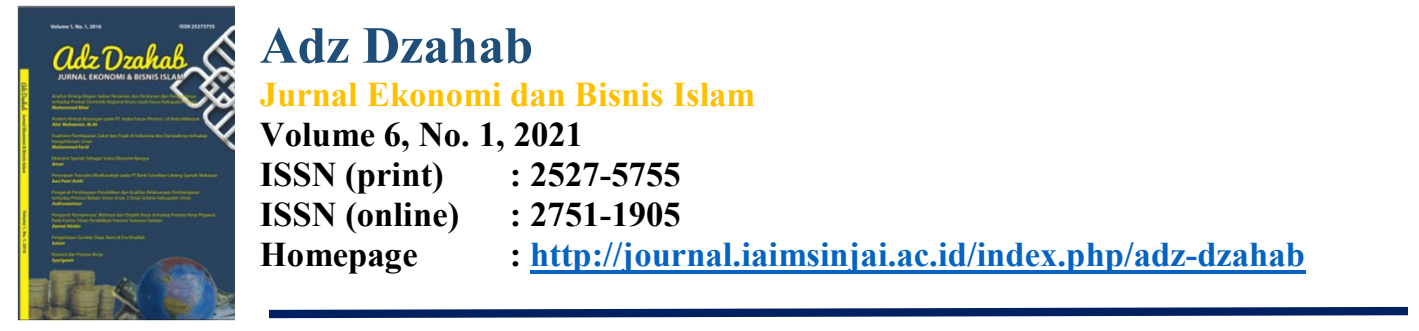

Literasi ekonomi dapat dikatakan segala pengetahuan yang berhubungan dengan kegitan ekonomi, misalnya pemanfaatan pendapatan untuk sebuah konsumsi, seving dan berinvestasi, atau bagaimana melakukan sebuah kegitan produksi, distribusi dan pemasaran serta melakukan sebuah proses perdagangan. Dalam artian literasi ekonomi merupakan instrument untuk merubah tingkah laku seseorang dari tidak cerdas menjadi cerdas dalam bidang ekonomi (Sina 2012). Dapat disimpulkan bahwa literasi ekonomi sendiri merupakan suatu kemampuan yang ada dalam diri seseorang sebagai akibat dari preses transformasi pembelajaran yang telah dilaluinya untuk memahami permasalahanpermasalahan ekonomi sehingga dapat mengetahui langkah-langkah dan mengambil keputusan yang tepat dalam bidang ekonomi untuk meningkatkan kesejahteraan.

Dalam pandangan islam sendiri literasi ekonomi merupakan kemampuan seseorang yang diperoleh dari proses pembelajaran untuk memahami maslah-masalah bidang ekonomi islam yang berbasis nilai-nilai dasar dalam islam untuk menentukan suatu tidakan dalam praktek ekonomi untuk meningkatkan kesejahteraan. Aktif terhadap praktek ekonomi islam membutuhkan pengetahuan agar tetap berada pada prinsip dasar nilai kebaikan islam (halal) dan terhindar dari unsur yang tidak baik (haram) dalam konsep islam. Manusia dalam praktek ekonomi dalam islam dipandang sebagai pemegang amah dengan begitu manusia harus mengikuti segala ketetapan dan ketentuan Allah karena hal ini tidak bersifat mekanistis dalam alam dan manusia semata melainkan juga bersifat teologis (Fauzia, 2014). Nilai-nilai islam ini tergambarkan dengan sangat jelas dan sangat ditegaskan kedalam tiga aspek yang paling mendasar dalam ilmu ekonomi islam (Fauzia, 2014) yaitu:

1. Akidah (tauhid)

Ekonomi islam berkenaan dengan aspek akidah (tauhid) berkenaan dengan dua hal, pertama : pemahaman ekonomi yang sifatnya ilahiyah, pemahaman ini berlandaskan pada tauhid uluhiyyah. Hal ini tercermin dalam diri seseorang bahwa ketika dia meyakini keberadaan Allah dan menyembah-Nya karena kapasitas-Nya sebagai dzat yang disembah maka secara prakteknya senantiasa meluruskan niat untuk beribadah hanya kepada Allah. Dengan kondisi seperti ini seseorang akan senantiasa mengerjakan kebaikan dan menolak segala bentuk pekerjaan buruk dan merugikan orang lain. Kedua: pemahaman ekonomi rabbaniyah, pemahaman ini berlandaskan pada tauhid rububiyah. Hal ini tercermin dalam diri seseorang bahwa Allah adalah pencipta dan pengatur alam semesta dan sumber dari segala rezeki. Dengan merefleksikan nilai akidah (tauhid) ini, seseorang akan senantiasa sadar bahwa segala yang ada di muka bumi ini adalah amanah yang mesti dikelolah dengan baik untuk memperoleh kesejahteraan bersama.

2. Hukum (syari'ah)

Dalam aspek hukum (syari'ah) praktek ekonomi dalam islam berlandaskan pada Al-Qur'an dan Hadis, praktek ini sangat diperbolehkan bahkan sangat dianjurkan selagi mendatangkan manfaat baik dan tidak terdapat larangaan didalamnya. Sebagaiman hadis Rasulullah SAW yang artinya : "Segala sesuatu (dalam hal muamalat) boleh dilakukan, sampai ada dalil yang mengharamkannya."

\section{Akhlak}

Selain dari pada aspek akidah dan hukum selanjutnya adalah aspek akhlak. Aspek akhlah atau moral selalu menjadi penegasan awal dalam setiap Al-Qur'an dan Hadis yang menangkut pembahasan ekonomi dalam islam. Dalam perspektif Islam, akhlak mulia merupakan hasil dari penerapan syariah (ibadah dan muamalah) yang dilandasi oleh pondasi akidah yang kokoh. Di ibarat sebuah bangunan, akhlak merupakan kesempurnaan dari bangunan tersebut setelah pondasi dan bangunannya kuat dalam hal ini akidah dan syariah islam. Suatu keniscaaan bahwa akhlah mulia akan terwujud pada diri seseorang 


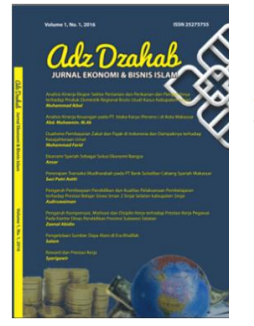

Adz Dzahab

Jurnal Ekonomi dan Bisnis Islam

Volume 6, No. 1, 2021

ISSN (print) : 2527-5755

ISSN (online) : 2751-1905

Homepage : $\quad$ http://journal.iaimsinjai.ac.id/index.php/adz-dzahab

jika ia memiliki akidah dan syariah yang benar (Pratama, 2019). Berbicara soal ekonomi tanpa adanya akhlak atau moral akan memnghancurkan perekonomian itu sendiri. Sangat lazim terdengar profesionalitas tanpa integritas akan melahirkan ketimpangan dalam perekonomian. Maka demikian aspek ini adalah hal krusial pada perekonomianIslam.

Ketiga aspek ini saling terkait dan tidak terpisahkan satu dan lainnya dalam sistem ekonomi islam. Ekonomi dalam islam yang bertujuan untuk kemaslahatan manusia tidak semerta-merta melaksanakan segala bentuk aktifitas lantas mengabaikan ketiga aspek dasar dalam ekonomi islam. Seseorang dikatakan paham terhadap literasi ekonomi islam ketika dia mampu memahami secara mendasar teori dan konsep dasar dalam praktek ekonomi islam yaitu memiliki niat yang lurus dalam praktek ekonomi, meyakini bahwa segala rezeki datangnya dari Allah Sang pemilik alam semesta dan senantiasa menegakkan norma dan etika dalam praktek yang dijalankannya.

\section{Simpulan}

Konsep kewirausahaan terus berkembang seiring dengan perkembangan pemikiran barat hingga menyebar ke negara-negara lain termasuk Indonesia. Pada dasarnya kewirausahaan merupakan suatu sikap, jiwa dan kemampuan kreatifitas dan berinovasi guna menghasilkan nilai tambah ekonomi terhadap sesuatu yang diusahakannya. Kewirausahaan yang berakarkakan kata wirausaha sering disamakan dengan istilah wiraswasta dalam berbagai literatur di Indonesia padahal kedua hal ini adalah hal yang berbeda. memang keduanya sama-sama menjalankan usaha namun wiraswasta monoton pada proses pengelolaan usaha untuk memenuhi kebutuhan hidup semata sedangkan wirausaha menekan pada pengelolaan usaha secara kreatif dan inovatif untuk terus berupaya mengembangkan usahanya agar memperoleh nilai tambah. Kehadiran revolusi industry 4.0 memaksakan praktek kewirausahan untuk menyesuikan diri kedalam sistem yang berbasis digitalisasi.

Perkembangan teknologi berbasis jaringan internet dapat memberikan nilai tambah, hal ini dapat dilihat dari pertukaran informasi dan komunikasi tidak hanya terjadi antar manusia dan mesin saja, namun antar mesin itu sendiri. Industri 4.0 yang terkoneksi secara global melalui internet banyak melahirkan aplikasi berbasis jaringan yang dapat memotong gerak, langkah, dan bahkan sistem dalam praktek kewirausahaan. Kehadiran berbagai macam aplikasi online shop seperti (Toko Pedia, Lazada, Shopee dan lain-lain) merupakan bentuk pemotongan sistem pemasaran. Dalam sistem transaksi kemudian juga ikut mengalami perubahan dengan munculnya berbagai platform pembayaran (OVO, GOPAY, DANA) yang berkembang melalui sistem jaringan dan terkoneksi dengan sistem perbankkan.

Islam menggambarkan karakter tersendiri seorang wirausaha yang sesuai dalam Al-Quran dan Hadis serta keteladanan Rasulullah diantarana adalah : iman, takwa, moralitas, shiddiq (jujur), amanah (dipercaya), tabligh (memiliki sifat komunikatif), fathanah (memiliki kecerdasan), disiplin, visioner, dan empati atau peduli. Dalam berwirausaha diperlukan sebuah landasan berupa literasi yang dalam dunia islam dikenal sebagai literasi ekonomi islam yang dalam defenisinya merupakan kemampuan seseorang yang diperoleh dari proses pembelajaran untuk memahami maslah-masalah bidang ekonomi islam yang berbasis nilai-nilai dasar dalam islam untuk menentukan suatu tidakan dalam praktek ekonomi. 


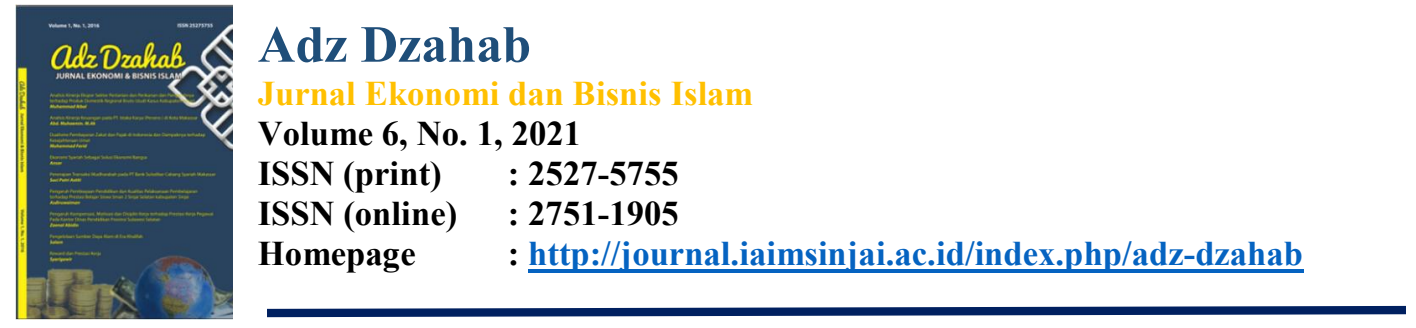

Ada dua pendekatan yang dapat dijadiakan sebagai strategi dalam membangun dan menghadapi revolusi industri 4.0, yaitu dengan pendekatan sumber daya dan pendekatan pengetahuan. Pada pendekatan sumberdaya ini, ada empat hal mendasar yang mesti dibangun dalam pribadi wirausaha, yaitu kemampuan menggerakkan, kemampuan mengorganisir, professional dengan menerapkan nilai-nilai islam, teladan dalam bentuk keteladanan dalam pribadi Rasulullah. Selanjutnya pada pendekatan pengetahuan ini, perlunya memahamkan literasi ekonomi dalam nilai-nilai islam yang bersumber pada AlQuran dan hadis.

Nilai-nilai dalam islam tergambarkan dengan sangat tegas kedalam tiga aspek yaitu : akidah (tauhid), hukum (syari'ah), dan akhlak. Seseorang dikatakan paham terhadap literasi ekonomi islam ketika dia mampu memahami secara mendasar teori dan konsep dasar dalam praktek ekonomi islam yaitu memiliki niat yang lurus dalam praktek ekonomi, meyakini bahwa segala rezeki datangnya dari Allah Sang pemilik alam semesta dan senantiasa menegakkan norma dan etika dalam praktek yang dijalankannya.

\section{DAFTAR PUSTAKA}

Prasetyo, H., \& Sutopo, W. 2018. Industri 4.0: Telaah Klasifikasi Aspek Dan Arah Perkembangan Riset. J@ati Undip: Jurnal Teknik Industri. Vol 13 (1)

Sartono, Sawal., Sutrismi, Sri., Wahyuandari, Wenni. 2014. Analisis Pertumbuhan Kewirausahaan Dan Efektifitas Kelembagaan di Kabupaten Tulungagung. Jurnal Universitas Tulungagung BONOROWO. Vol 2 (1)

Baharun, Hasan., \& Niswa, Harisatun. 2019. Syariah Branding; Komodifikasi Agama Dalam Bisnis Waralaba di Era Revolusi Industri 4.0. Jurnal Penelitian Sosial Keagamaan INFERENSI. Vol 13 (1)

Diandra, Didip. 2019. Kewirausahaan Dan Urgensinya Dalam Revolusi Industri 4.0. Jurnal SENMEA Fakultas Ekonomi UN PGRI Kediri Vol 1 (1)

Fauziah, Ika Yunia., Riayadi, Abdul Kadir. 2014. Prinsip Dasar Ekonomi Islam Perspektif Maqashid Syariah. Jakarta : Kencana.

Triningtyas, Diana Ariswanti. 2016. Dasar-Dasar Kewirausahaan. Jawa Timur : CV AE Media Grafika.

Zimmerer, W. Thomas dan Norman, M. Scarborough. 2002. Pengantar Kewirausahaan Dan Manajemen Bisnis Kecil (Edisi Bahasa Indonesia). Jakarta: PT. Rineka Cipta.

Frinces, Z. Heflin. 2010. Pentingnya Profesi Wirausaha Di Indonesia. Jurnal Ekonomi \& Pendidikan (Program Magister Manajemen STIE Mitra Indonesia Yogyakarta). Vol 7 (1).

Al Idrus, Salim. 2017. Strategi Pembelajaran Kewirausahaan : Aplikasi Pembelajaran Mata Kuliah Kewirausahaan di Perguruan Tinggi. Malang : Media Nusa Creative

Kamaluddin. 2019. Kewirausahaan Dalam Pandangan Islam. Proseding Seminar NasionalKewirausahaan (SNK). Vol 1 (1). Hal. 302-310

Habibullah, Eka Sakti. 2018. Prinsip-Prinsip Muamalah Dalam Islam. Jurnal Perbankan Syariah AD-DEENAR. Vol 2 (1)

Ridwan, Samir Abdul Hamid. 1996. Aswaq al-Awraq al-Maliyah cet III, Cairo.

Gumusay, Ali Aslan. 2015. Entrepreneurship From An Islamic Perspective. Journal of Business Ethics, Vol. 130 (1), hal. 199-208.

Haroen, Nasrun. 2007. Fiqh Muamalah. Jakarta : Gaya Media Pratama

Hijriah, Hanifiyah Yuliatul. 2016. Spiritualitas Islam dalam Kewirausahaan. Jurnal Peradaban Islam TSAQAFAH Vol. 12 (1), Hal. 187-208 


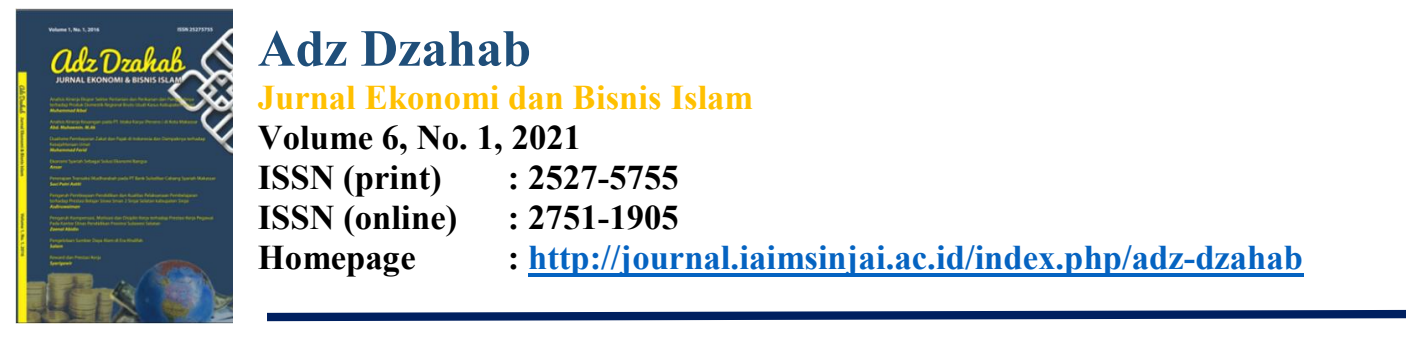

Suharyadi, Arissetyanto Nugroho dkk. 2007. Kewirausahaan : Membangun Usaha Sukses Sejak Usia Muda. Jakarta: Salemba Empat

Schwab, K. 2017. The Fourth Industrial Revolution. Crown Publishing, US.

Roblek, V., Mesko, M., \& Krapez, A. 2016. A Complex View of Industry 4.0. The SAGE

Vaidya, S., Ambad, P., Bhosle, S. 2018. Industry 4.0 - A Glimpse, $2^{\text {nd }}$ International Conference on Materials Manufacturing and Design Engineering. Published by Elsevier B.V, p.233-238.

Sundari, Cisilia. 2019. Revolusi Industri 4.0 Merupakan Peluang Dan Tantangan Bisnis Bagi Generasi Milenial Di Indonesia. Prosiding SEMINAR NASIONAL DAN CALL FOR PAPERS Fakultas Ekonomi Universitas Tidar

Sina, Peter Garlans. 2012. Analisis Literasi Ekonomi. Jurnal economia. Vol.8 (2)

Wahl, M, 2015. Strategic Factor Analysis for Industry 4.0. Journal of Security and Sustainability Issues, Vol.5, (2) Hal 241-247.

Kementerian Pendidikan dan Kebudayaan, "Kamus Besar Bahasa Indonesia edisi V (daring)," sumber dari: https://kbbi.kemdikbud.go.id/entri/literasi diakses pada tanggal 9 maret 2020

Pakistianingsih, Arini. 2014. Surabaya Sebagai Kota Literasi. Surabaya: Pelita Hati

Nugraha, Ahmad Lukman., Sunjoto, Arie Rachmat. 2019. Signifikansi Penerapan Literasi Ekonomi Islam di Perguruan Tinggi: Kajian Teoritis. Jurnal Ekonomi Islam Universitas Darussalam Gontor Vol. 5 (1)

Burkhardt, Gina. Dkk. 2003. enGaunge 21st Century Skills: Literacy in The Digital Age. North Central Regional Educational Laboratory and the Metiri Group

Pratama, Dian Arif Noor. 2019. Tantangan Karakter Di Era Revolusi Industri 4.0 Dalam Membentuk Kepribadian Muslim. Jurnal Manajemen Pendidikan Islam Al-Tanzim Universitas Sunan Kalijaga, Yogyakarta Vol. 03 No. 01, p. 198-226.

Rusdiana, A. 2018. Kewirausahaan Teori Dan Praktik . Bandung: Pustaka Setia

Satya, Venti Eka. 2018. Strategi Indonesia Menghadapi Industri 4.0. Jurnal Pusat Penelitian BIDANG EKONOMI DAN KEBIJAKAN PUBLIK Badan Keahlian DPR RI (Info Singkat). Vol. 10 No. 09

Saptono. (2011). Dimensi-dimensi Pendidikan Karakter. Jakarta: Erlangga. 